\title{
Psychological Intervention in Portuguese College Students: Effects of Two Career Self-Management Seminars
}

\author{
Joana Carneiro Pinto Nazaré Loureiro Maria do Céu Taveira
}

This article describes the evaluation of a psychological intervention - the Career SelfManagement Seminar, Version A, for undergraduate students, and Version B for postgraduate students — developed to support Portuguese college students in career exploration, goal setting, design and implementation of action plans, and decision-making. At total of 120 participants from CSMS- $A$ (experimental group, $n=58$; control group, $n=62)$ and 98 from CSMS-B (experimental group, $n=62$; control group, $n=36)$ were assessed by the Career Exploration Survey according to a pretest and posttest plan. Results demonstrate a significant increase in most of the cognitive, behavioral, and affective career exploration dimensions among the CSMS-A and CSMS-B experimental groups.

We live in a world of permanent change in educational, professional and social spheres affecting people's trajectories (Gabinete de Planeamento, Estratégia, Avaliação e Relações Internacionais, 2008; Observatório da Ciência e do Ensino Superior, 2004). In fact, careers are no longer stable and predictable (Arnold, 1997), and they demand adaptable skills. Therefore, recent vocational literature has highlighted the importance of developing and assessing comprehensive career selfmanagement programs in order to promote career skills in people, regardless of the person's academic or professional qualifications, and with an intentional and regular evaluation strategy (Brown \& Lent, 2005).

According to Greenhaus and Callanan (1994), career management is a continuous and dynamic process consisting of selfexploration and development, academic and professional exploration, goal setting, development and implementation of career strategies, and obtaining feedback in order to solve career problems and make career decisions. Noe (1996) described career management as a tridimensional process based on career exploration, career goal setting, and the implementation of interpersonal and intrapersonal strategies. More recently, King $(2000,2001,2004)$ presented a career self-management cycle in organizations that comprises behaviors, causes, and effects and that identifying gatekeepers and selecting, implementing and evaluating career strategies.

Career development seminars, thus, are appropriate for acquiring, training of, and improvement of career management skills, including career self-efficacy beliefs, selfexploration and development, knowledge of academic and professional opportunities, and career plans and decision making (Halasz $\&$ Kempton, 2000; Kenny, Blustein, Haase, Jackson, \& Perry, 2006; Taveira, 2009).

Considering the substantial number of career intervention models for different populations, a basic concern must be addressed is if all types of interventions are equally effective. Despite its importance, few psychologists

Joana Carneiro Pinto is Professor of Psychology at Portuguese Catholic University. Nazaré Loureiro is a Psychologist. Maria do Céu Taveira is Professor of Psychology at University of Minho. 
evaluate their interventions (Schmidt, 1996). Previous research has addressed this question and found a lack of an understanding of the elationship between research and practice (Paisley \& Hayes, 1997), a lack of knowledge about suitable research techniques (Lewis, 1983; Paisley \& Hayes, 1997), time constraints, concerns about possible negative results (Lewis, 1983; Lombana, 1985), and the belief that it is not always necessary to systematically evaluate the efficacy of interventions are the main reasons why professional do not invest in this scientific activity. According to Patton (1997), career intervention evaluation must be an intentional and systematic collection of information in order to make accurate judgments about counselling, to improve its efficacy, and to make changes for future interventions. It must include an assessment of the process and results according to the clients' perspective (Gerstein \& Amos, 1986).

Meta-analytic studies concerning career intervention have proven its efficacy, related to satisfaction, assurance in career choices, and vocational maturity, of about $62 \%$ in intervention groups compared to a control group (Brown \& Krane, 2000). Among college students, career seminars seem to be one of the most acceptable strategies used to promote vocational identity, to define realistic life goals, and to develop strategies and skills that will impact their academic and professional domains (Luzzo, 2000), especially if designed to address the characteristics and needs of specific population groups (e.g., Kivlighan, Coleman, \& Anderson, 2000).

The ability to effectively manage a career is one of the most valued capabilities in today's professional world. Nevertheless, research on career management intervention is still scarce (Pinto, 2010). Therefore, this study aimed to evaluate the effectiveness of the Career Self-Management Seminar (CSMS, version A for undergraduates and Version B for postgraduates; Taveira et al., 2007) developed by psychologists to help students in career exploration, goal setting, career plans, career problem solving, and decision making (Pinto, 2010; Taveira, 2009).

\section{METHOD}

Participants were 218 college students, from both sexes (men, $n=89$, 40.8\%; women, $n=129,59.2 \%)$, mostly Caucasian, with ages ranging from 18 to 49 years old $(M=25.42$, $S D=5.90)$. A total of 120 participants attended the CSMS-A (experimental group, $n=58$; control group, $n=62)$, and 98 attended the CSMS-B (experimental group, $n=62$; control group, $n=36$ ). This study used a quasiexperimental design with nonrandom experimental and control groups, given that the sample included career counseling clients who had voluntarily enrolled in a university counseling center during the previous three academic years to satisfy self-perceived career management intervention needs. Differences between groups were controlled using a pretest score as a baseline and a post-test score at the end of the intervention. Participants were informed about the goals of the study, and confidentiality was assured.

For assessment purposes, the CSMS-A and $B$ used the Portuguese version of the Career Exploration Survey (CES; Stumpf, Colarelli, \& Hartman, 1983; adapted by Taveira, 1997). This self-administered survey has 53 items with a Likert-type response format and one with an open format. The items are organized into three major components: (a) five career beliefs comprising: (i) employment outlook, (ii) certainty of exploration outcomes, (iii) external search instrumentality, (iv) internal search instrumentality, and (v) importance of preferred position; (b) four career behaviors comprising (i) environment exploration, (ii) self-exploration, (iii) intended systematic 


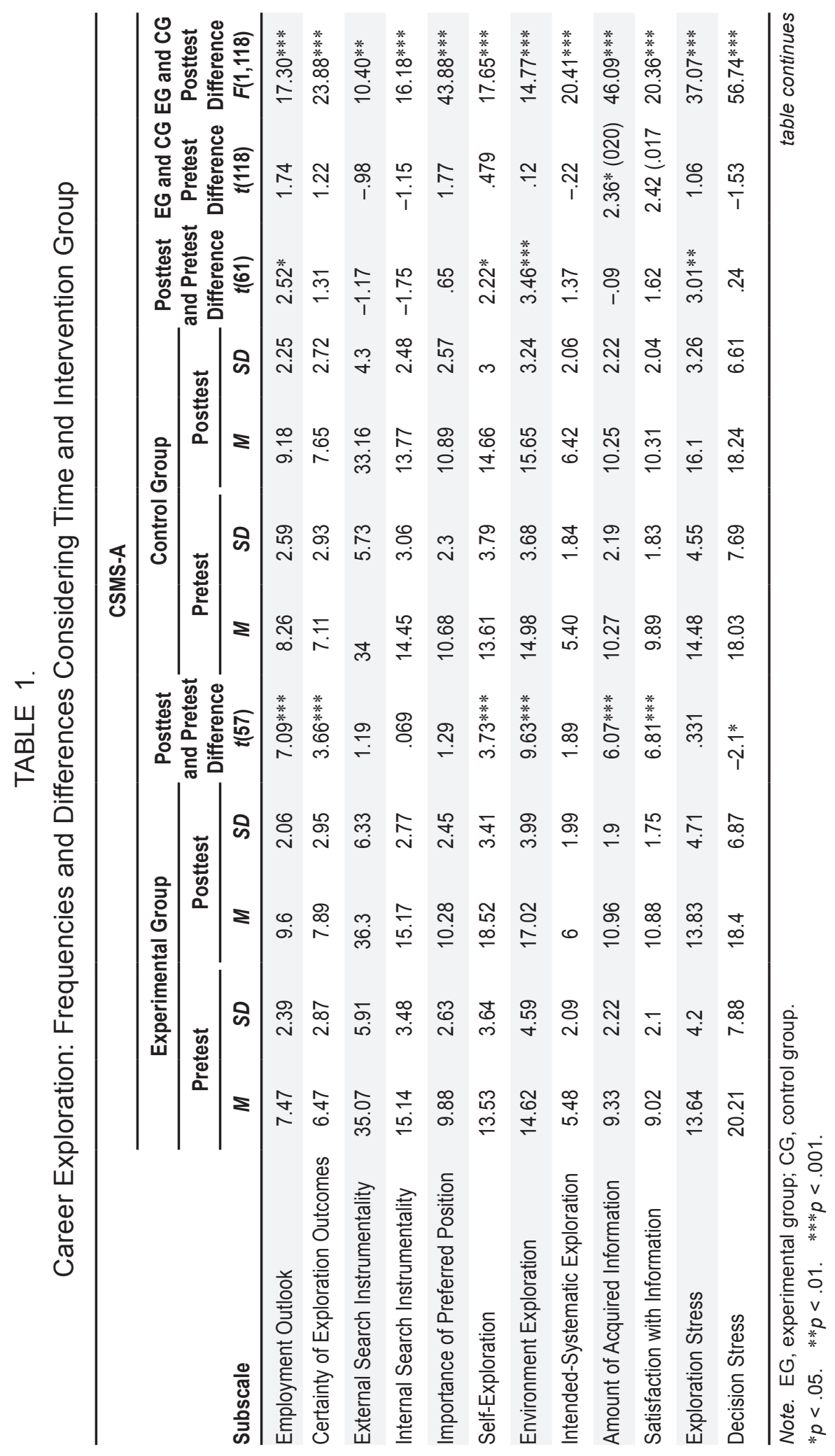


International Research

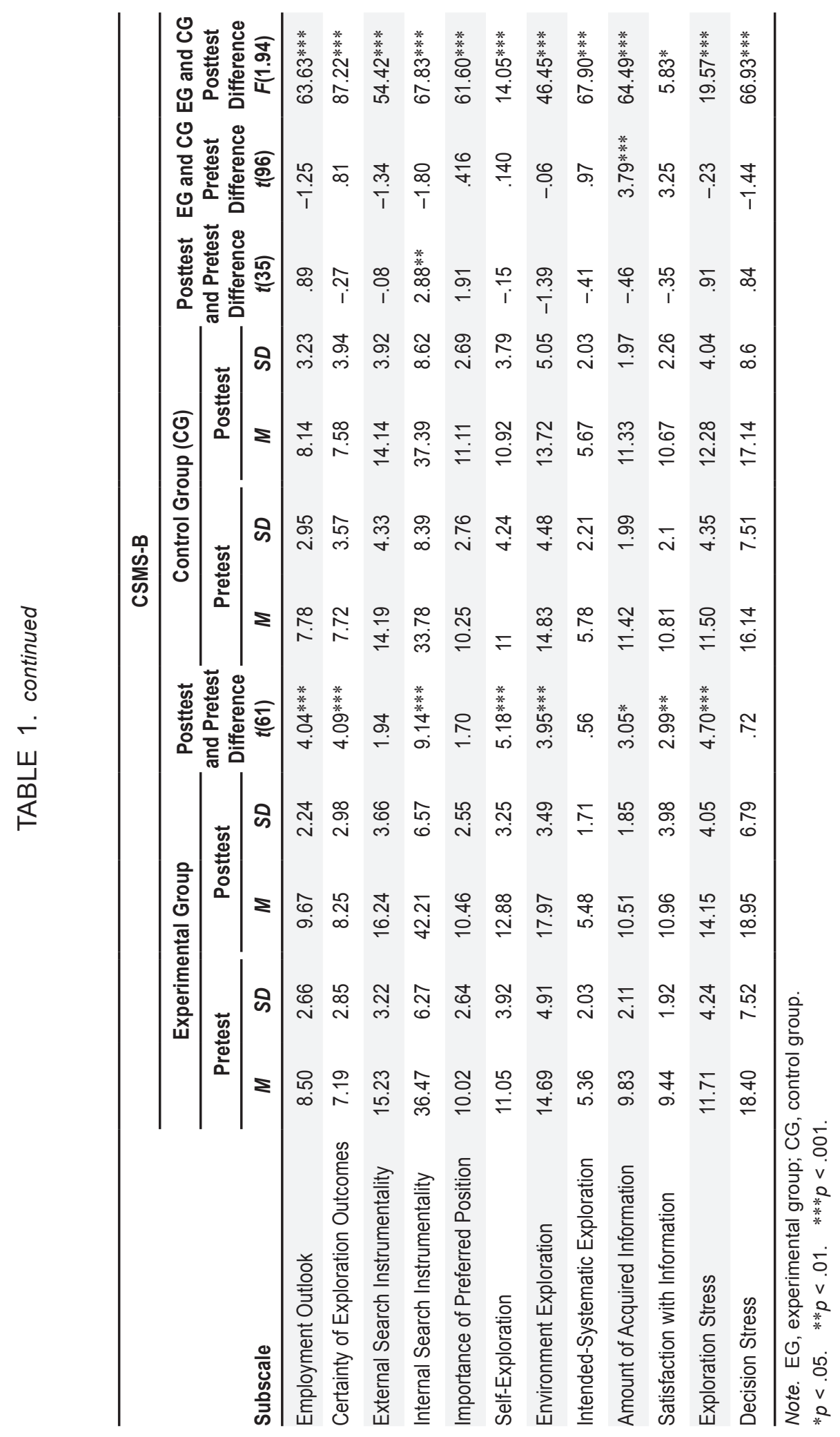


exploration, and (iv) amount of acquired information; and (c) three career reactions comprising (i) satisfaction with information, (ii) exploration stress, and (iii) decision stress. Studies undertaken by Taveira (1997) indicated the suitability of CES for use among Portuguese adolescents (Taveira \& Moreno, 2003) and for adult university and nonuniversity students (Silva \& Taveira, 2010, p. 211).

This survey was used considering that both seminars intended to encourage participants to develop an active role in career exploration in order to effectively solve their career difficulties. In this sense, CSMS-A and B enabled participants to: (a) analyze and reflect about their personal, academic, professional, social, and leisure history; (b) encourage self-appreciation through consciousness about personal values, interests, and skills learned in different life contexts; (c) foster the recognition of social support networks and the influences they exert in individual career decisions; and (d) support the search and questioning of information on education, training, and professional opportunities and of its application in everyday life. CSMS-A is aimed at all students in the intermediate years of the 1st and 2nd Bologna cycles and comprises a total of nine weekly sessions of 120 minutes each in groups of eight to 10 participants. CSMS-B is for all students in the intermediate years of the 3rd Bologna cycle and consists of six weekly sessions of 120 minutes each, performed in groups of four to seven participants.

\section{RESULTS}

As indicated in Table 1, for CSMS-A, experimental group differences between post- and pretests were statistically significant for the following subscales: Employment Outlook, $t=7.09, p=.000$; Certainty of Exploration Outcomes, $t=3.66, p=.001$; Self-Exploration, $t=3.73, p=.000$; Environment Exploration, $t=9.63, p=.000$; Amount of Acquired Information, $t=6.07, p=.000$; Satisfaction with Information, $t=6.81, p=.000$; and Decision Stress, $t=-2.10, p=.041$. Control group differences were statistically significant for the following subscales: Employment Outlook, $t=2.52, p=.014$; Self-Exploration, $t=2.22, p=.030$; Environment Exploration, $t=3.46, p=.001$; and Exploration Stress, $t=3.04, p=.004$.

For the experimental group for CSMS-B, differences were statistically significant for the following subscales: Employment Outlook, $t=4.04, p=.000$; Certainty of Exploration Outcomes, $t=4.09, p=.000$; Internal Search Instrumentality, $t=9.14$, $p=.000$; Self-Exploration, $t=5.18, p=.000$; Environment Exploration, $t=3.95, p=.000$; Amount of Acquired Information, $t=3.05$, $p=.030$; Satisfaction with Information, $t=2.99, p=.004$; and Exploration Stress, $t=4.70, p=.000$. The control group attained statistically significant differences between post- and pretests for the Internal Search Instrumentality subscale, $t=2.88, p=.007$.

For both seminars, the mean difference analysis between experimental and control groups at pretest revealed statistically significant differences for the Amount of Acquired Information in favor of the control group in the CSMS-A, $t=2.36, p=.020$, and in favor of the experimental group in the CSMS-B, $t=3.79, p=.000$. The mean difference analysis between experimental and control groups at posttest, with the results of the pretest moment as covariation variable, revealed statistically significant differences for all of the career exploration subscales, with higher mean values in the experimental group, except for Importance of Preferred Position, Intended-Systematic Exploration, and Exploration Stress in the CSMS-A and Importance of Preferred Position, Intended- 
Systematic Exploration and Amount of Acquired Information in the CSMS-B.

\section{DISCUSSION AND CONCLUSION}

The results suggest that both career selfmanagement seminars are effective at promoting gains in the cognitive, behavioral, and affective dimensions of career exploration. In fact, after attending the seminar, those in the experimental groups showed a higher degree of belief about the possibility of achieving a desired position in the labor market. They also increased the strength of their beliefs on the instrumental value of career exploration and showed higher information satisfaction. Stumpf and colleagues (1983) among others (e.g., Langer, 1975; Taveira, 1997) have demonstrated that these types of beliefs are related to the activation and quality of the exploration process. These results also reflect what could be theoretically expected (e.g., Barak, Carney, \& Archibald, 1975; Stumpf et al., 1983; Taveira, 2000), indicating that career exploration incites emotional reactions (in this case, satisfaction) when the information is provided in ways that are adequate for the clients' characteristics and the needs of vocational intervention. Moreover, considering that reactions to career exploration are related to future beliefs and behaviors, one can expect that participants in the CSMS can become more confident and involved in future career exploration processes.

This study helps to demonstrate the applicability and usefulness of career selfmanagement in educational, training, and development contexts. Hitherto, there has been a strong association between career management and organizational contexts (e.g., King, 2000; Noe, 1996), making it imperative to analyze the training and usefulness of career management strategies in early stages and in school environments, such as higher education (e.g., Lau \& Pang, 2000; RodríguezMoreno, 2005). Therefore, the development of intervention programs with a primary focus on this issue should be considered as a necessary investment (Nyquist \& Wulff, 2000), encouraging the development of career promotion strategies and methods that allow every person to increase his or her control and responsibility about career management.

Correspondence concerning this article should be sent to Maria do Céu Taveira, Psychology Research Centre, Campus of Gualtar, University of Minho, 4710-057 Braga,Portugal; ceuta@psi.uminho.pt

\section{REFERENCES}

Arnold, J. (1997). Managing careers into the 21st century. London, England: SAGE.

Barak, A., Carney, C. G., \& Archibald, R. D. (1975). The relationship between vocational information seeking and educational and vocational decidedness. Journal of Vocational Behavior, 7, 148-159.

Brown, S. D., \& Krane, N. E. (2000). Four (or five) sessions and a cloud of dust: Old assumptions and new observations about career counseling. In: S. Brown \& R. Lent, (Eds.). Handbook of counseling psychology (3rd ed., pp. 740-749). New York, NY: John Wiley \& Sons.

Brown, S. D., \& Lent, R. W. (2005). Career development and counseling: Putting theory and research to work. Hoboken, NJ: John Wiley \& Sons.
Gerstein, M., \& Amos, M. A. (1986). Implementation and evaluation of adult career development programs in organizations. Journal of Career Development, 12, 210-218.

Gabinete de Planeamento, Estratégia, Avaliação e Relaçôes Internacionais. (2008). Número de diplomados no ensino superior [1997-1998 a 2005-2006]. Lisbon, Portugal: Author.

Greenhaus, J. H., \& Callanan, G. A. (1994). Career management (2nd ed.). Fort Worth, TX: Dryden Press.

Halasz, T. J., \& Kempton, C. B. (2000). Career planning workshops and courses. In D. A. Luzzo (Ed.), Career counseling of college students: An empirical guide to strategies that work (pp.157-172). Washington, DC: American Psychological Association. 
Kenny, M. E., Blustein, D. L., Haase, R. F., Jackson, J., \& Perry, J. C. (2006). Setting the stage: Career development and the student engagement process. Journal of Counseling Psychology, 53, 272-279.

King, Z. (2000). The development and initial test of a theory of career self-management (Unpublished doctoral thesis). University of London.

King, Z. (2001). Career self-management: A framework for guidance of employment adults. British Journal of Guidance \& Counselling, 29(1), 66-78.

King, Z. (2004). Career self-management: Its nature, causes and consequences. Journal of Vocational Behavior, 65, 112-133.

Kivlighan, D. M., Jr., Coleman, M. N., \& Anderson, D. C. (2000). Process, outcome, and methodology in group counselling research. In S. D. Brown \& R. W. Lent (Eds.), Handbook of counselling psychology (3rd ed., pp. 767-796). New York, NY: Wiley.

Langer, E. (1975). Illusions of control. Journal of Personality and Social Psychology, 32, 311-328.

Lau, A., \& Pang, M. (2000). Career strategies to strengthen graduate employees' employment position in the Hong Kong Labour Market. Education + Training, 42, 135-149.

Lewis, J. D. (1983). Guidance program evaluation: How to do it. School Counselor, 31, 111-119.

Lombana, J. H. (1985). Guidance accountability: A new look at an old problem. School Counselor, 32, 340-346.

Luzzo, D. A. (2000). Career counseling of college students: An empirical guide to strategies that work. Washington DC: American Psychological Association.

Nyquist, J., \& Wulff, D. H. (2000). Re-envisioning the Ph.D.: Recommendations from national studies on doctoral education. University of Washington, Seattle. Retrieved from http:// depts.washington.edu/envision/project_resources/national_ recommend.html

Noe, R. A. (1996). Is career management related to employee development and performance? Journal of Organizational Behavior, 17, 119-133.

Observatório da Ciência e do Ensino Superior. (2004). Estudos pós-graduados [Post-graduate studies]. Lisbon, Portugal: Direcçáo de Serviço de Estatísticas e Indicadores.

Paisley, P. O., \& Hayes, R. I. (1997). Research in school counseling. In L. Loesch \& N. Vacc (Eds.), Research in counseling and therapy (pp. 7-9). Greensboro, NC: ERIC/ CASS.

Patton, M. Q. (1997). Utilization-focused evaluation: The new century text. Thousand Oaks, CA: SAGE.

Pinto, J. C. (2010). Gestão Pessoal da Carreira: Estudo de um Modelo de Intervenção Psicológica com Bolseiros de Investigação [Career self-management: study of a psychological intervention model with research grant-holders] (Doctoral dissertation). University of Minho, Portugal.
Rodríguez-Moreno, M. L. (2005). Las demandas sociales y el mercado laboral ante la integración Europea del conocimiento universitario. Cuadernos de Integración Europea, 2, 54-68.

Schmidt, J. (1996). Assessing school counseling programs through external reviews. School Counselor, 43, 114-123.

Silva, F., \& Taveira, M. C. (2010). Competências de exploração vocacional de adultos náo-universitários [Vocational exploration skills in non-university adults]. In M. C. Taveira \& A. D. Silva, Desenvolvimento vocacional: Avaliação $e$ intervenção [Vocational development: Assessment and intervention], pp. 183-196. Braga: Associação Portuguesa para o Desenvolvimento da Carreira.

Stumpf, S. A., Colarelli, S. M., \& Hartman, K. (1983). Career exploration survey. Journal of Vocational Behavior, 22, 191-226.

Taveira, M. C. (1997). Exploração e desenvolvimento vocacional de jovens: Estudo sobre as relaçôes entre a exploraçâo, a identidade e a indecisäo vocacional [Exploration and vocational development of youth: A study on the relationship between career exploration, indecision and identity] (Doctoral dissertation). University of Minho, Portugal.

Taveira, M. C. (2000). Exploraçẫo e desenvolvimento vocacional de jovens: Estudo sobre as relaçôes entre a exploraçâo, a identidade, e a indecisão vocacional [Vocational exploration and development in youth: Study about the relations between vocational exploration, identity and indecision]. Braga, Portugal: University of Minho.

Taveira, M. C. (2009). Promoción de la empleabilidade profesional en la vida adulta: El papel de los seminarios de gestión personal de la carrera [Promotion of the employability in adult life: The role of the self-career management seminars]. Communication presented at X Seminario Permanente d'Orientación Profesional i Seminario International d'Orientación Profesional, Adultos emergentes, transiciones, i orientación profesional, MIDE, Barcelona, Spain.

Taveira, M. C., \& Moreno, M. L. R. (2003). Guidance theory and practice: The status of career exploration. British Journal of Guidance \& Counselling, 31, 189-208.

Taveira, M. C., Silva, A. D., Loureiro, M. N., Araújo, A., Faria, L., \& Pinto, J. C., \& Sousa, S. (2007), Seminário de Gestão Pessoal da Carreira - versão A, B, e C. [Self-Career Management Seminar - version A, B, and C.] (Unpublished manuscript). University of Minho, Portugal. 